\title{
Planning and Organizing the Projects in Team Co Čakovec, Croatia
}

\author{
Ratko Matotek \\ Međimurje-investa Co. Čakovec, Croatia
}

\begin{abstract}
The paper systemizes standard methods of planning, monitoring and controlling the realization of construction works in civil engineering projects and overviews the implementation of the methods in Team Co Čakovec from Croatia. The specificities of the methods are shown through the different construction works projects. Also, paper reviews the implementation, modification and improvement of existing methods for planning, monitoring and controlling the realization of projects in Team Co.
\end{abstract}

Key words: Plan, monitoring, control, S-curve.

\section{Introduction}

Numbers of researches carried out in the world and in Croatia are pointing to increasing trend of deadline's extensions and delays. For example, World Bank researches on around 1.600 projects show $70 \%$ average extensions and delays of initial deadline in $88 \%$ of projects. Similar researches are carried out in Croatia too. In goal of project realization within planed time, expenses and resources, company Team Co changed initial line organizational structure to functional and finally to matrix organizational structure that provided higher flexibility in project management. Parallel with organizational structure development, central work preparation and also sector of project preparation and realization developed.

\section{Planning}

Planning is a process in which events and activities in future processes are being predicted and then on basis of known data and documents, applied technology and work organization, their integration, dimensioning, allocation and realization control is pursued. Planning includes past (data and experience),

Corresponding author: Ratko Matotek, mag.ing. CE, research field: project management. E-mail: ratko@m-investa.hr. present (norm, calculation and control) and future (plan and projection). Task of planning is prediction of possible realization variants in advance and making a decision of best optimal way and its integration into a plan. Than assuring documents for control and work completion evaluation, documents for decision making and managing during completion. Database of plan and completion of past projects are made based on plan tracking. Goal of planning is to coordinate four variables (time, costs, resources and risks) through optimal usage of available resources by minimizing duration, costs and risks in project.

Planning is carried out through work in four phases, which can be all, or some of them cyclically repeated. Everything starts by creating an initial plan that is basis of optimal work distribution. During realization of work, control and comparison planed vs. realized is carried out as well as prognosis of further realizations. Depending on work stage and in relation with planed vs. realized, it's possible after prognostic state to make new plan, distribution or control.

This paper elaborates part of planning and organization of project that besides costs planning, resources and other elements refers to construction and tracking of completion of time plans.

Approach to planning can be partial, systematic, ad hoc and nihilistic. 
In phase of bidding, most of contractors are completely oriented on calculation of price, while planning of realization deadlines is less favored. The reason for such behavior is fear that in case of rejection of proposed time schedules their offer will be declined or expectation that with extremely short time schedule they will gain extra points. However, after contracting most of contractors very critically claim to time schedule. Most of contractors have approach hockey stick approach (slower beginning — faster ending), so they stretch initial activities and plan final activities in peak deadline that is very risky. In other words, completion is forced without quality preparation.

\section{Plans}

Plan, as a written document should be complete, clear, with possibility of data reconstruction, furthermore dynamic and legitimate. Completeness of the plan implies content of all activities required for completion of project. Also, plan must be readable and easy for understanding for all project's participants. Possibility of data reconstruction refers to reconstruction of all data and results within short time period on simplest way. In case of deviation from plan's completion, it is necessary to ensure input of changes for maintaining the goal with less additional actions and effort in plan. Also, it is very important that plan is accepted from all participants of the project.

Methods of planning can generally be divided on techniques of network planning and techniques of line planning (Gant chart, orthogonal plan, S-curve and histogram). Each of these techniques has a different way of presenting result that is type of information. Whole presentation of data, time report, time presentation of resource usage and dynamics of planed costs and profit enables usage of different planning techniques. The most common combination of methods of planning in civil engineering is network diagram - Gantt chart - S-curve or in simple projects Gantt chart - histogram - S-curve.

Plans, according to activities level, are divided to basic, overviewed and detailed. Basic plan is made in phase of biding and after signing of contract it is corrected according to contract time schedule. Usually it contains 10 to 40 summary activities and all key interim deadlines. Time scale of plan is month so plan is updated once a month.

Overview plan is made on basis of basic plan and includes contract interim deadlines and other significant deadlines for supplying equipment, materials, and documentation delivery by participants involved in the project. All activities (links) for construction and documentation, supply and procurement, implementation and realization, handover are shown in this plan. Usually it is a part of contracting documentation. Time scale of plan is month or week so plan is updated once a month or a week.

Detailed or operating plan represents further details of overview plan. It is made during realization of project and it can embrace total duration of realization, but it is often made for certain period; month, week or day. Time scale of plan often is week or day so plan is updated weekly or daily.

\section{Planning and Organizing the Projects in Team Co from Čakovec, Croatia}

Team Co has matrix organizational structure with strong central preparation of projects. Project manager is involved in creation of basic plan since the very beginning of possible future signed contract in bidding phase, His task is to contribute the creation of optimized plan with his experience form the realized

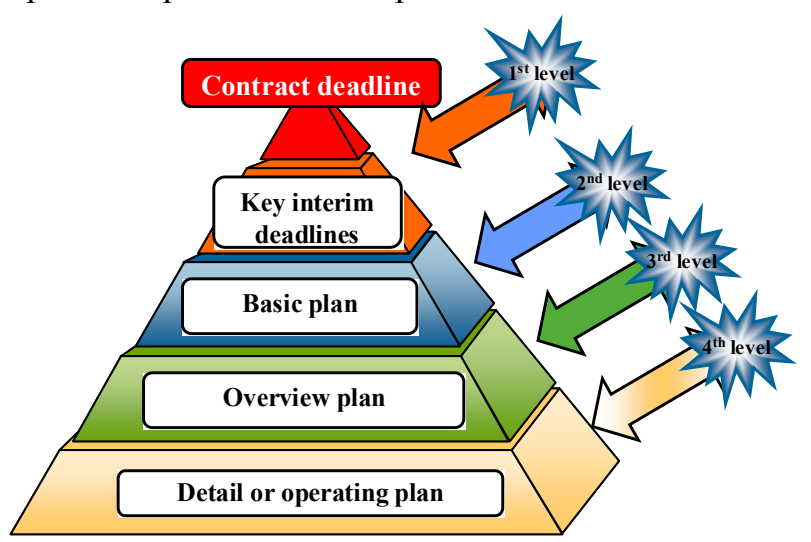

Fig. 1 Term plan ranking. 
projects. Every bid includes creation of term plan, weather it is demanded from the investor (or tender) or not, in the preparation and realization of projects sector in department for planning, monitoring and controlling. After the contract is signed, project is assigned to the project manager who is from that moment to the end responsible for the project success.

As project manager is involved in the bidding phase and creation of basic plan and with extra information there is no reason to avoid the creation of overview plan that contains key interim deadlines, latest dates of documentation delivery form the other participants in project that aren't within the organizational structure of the company, and also other obligations of the involved participants in project.

After the overview plan is created, project manager who is a member of central preparation sector approaches to the creation of detail plan with construction site staff.
Described organization avoids the standard process in small and also big companies. Planning in small companies is left to the construction site staffs who think of plan as a document for pressuring the investor or to be pressured by company management, but they are already pre-occupied and responsible for everything. Big companies have central planning in departments without participation of the construction site staff, so they think of plans like they are pushed upon and unrealistic. Consequences of both approaches are frightening that is boycott of plan. To avoid that, project manager in Team Co is a person, also member of central preparation and realization sector, responsible for project success. This approach means the link from site to the central sector over project manager and demand of legitimacy of plan is fulfilled, so all participants in the project accept the plan.

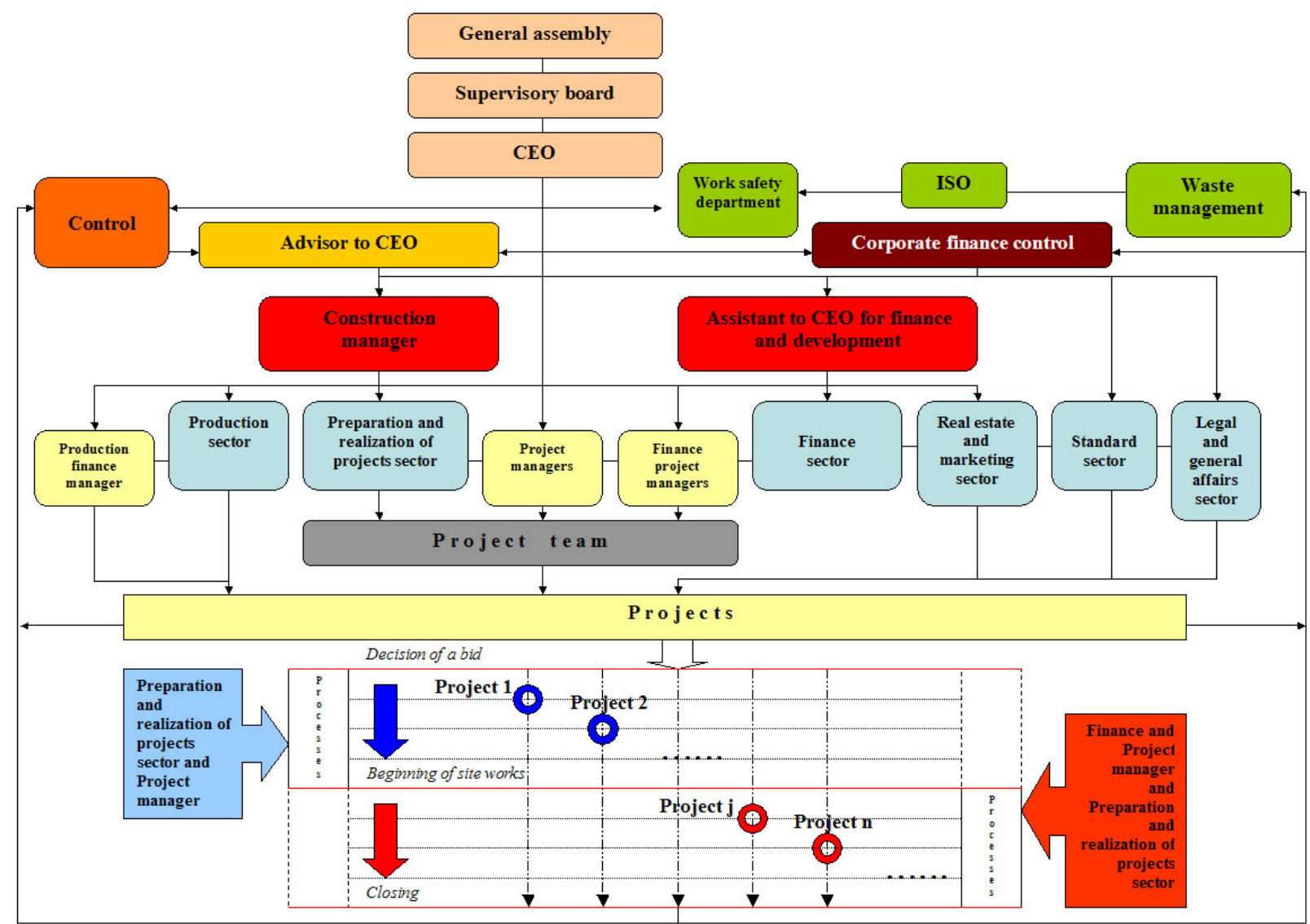

Fig. 2 Organizational structure scheme of Team Co. 
Gantt chart is used in Team Co for creation of basic, overview and detail plans. Network planning is used for the project phase that understands the construction works. After the plans are created work progress is monitored and by control and corrective actions affected on noticed changes and deviations from plan.

Project approach involves detailed plans that are created, usually, for three phases of the new building construction:

- construction works

- craft and installation works

- start-up and ending

Detailed plan and its related S-curve are created for every phase of the project. In every phase, at least two systems of monitoring and control are used, so the possibility of system error is minimized. Work progress monitoring on plan view was introduced because mentioned methods don't always show a clear picture about the work progress. This method provides a good overview for the higher level of company management. For example, construction work progress
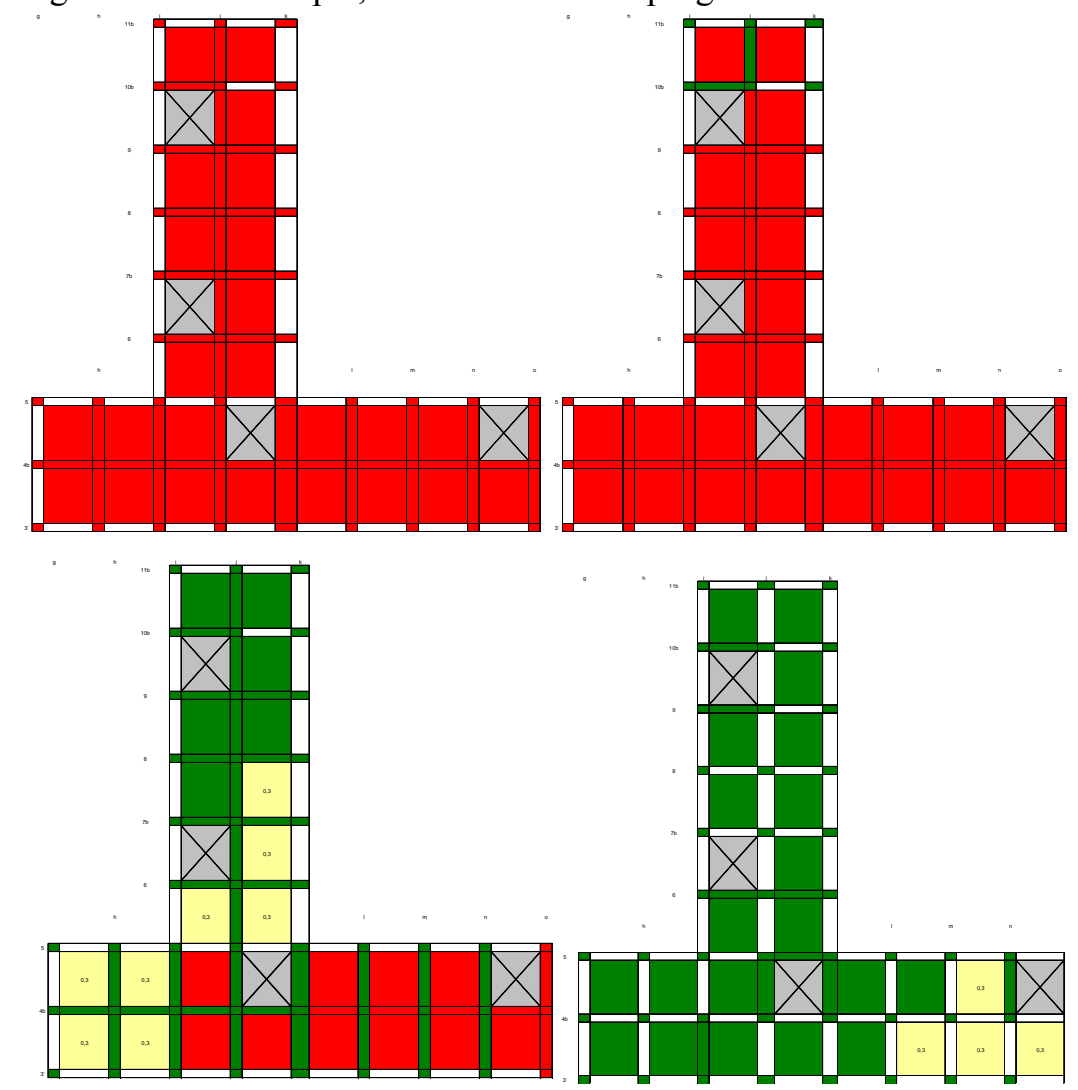

Fig. 3 Work progress monitoring on plan view during 6 weeks. is monitored by the quantity of the concrete built in, activity tracking by Gantt chart and plan view progress work.

Main focus during planning is simplicity, which means little input quantity but accuracy of interpretation of output data, so the decisions could be right and on time. Usage of S-curve method, as a simple graphic technique, has shown as a very good indicator of status, trend and prognosis of work progress, and also as a good basis for making decisions in project. Except S-curve, in planning, monitoring and controlling, histogram is used to show daily planned and completed quantities and resources. Main characteristic of project realization control system is the speed of reaction and possibility to forecast the future scenario.

Work progress monitoring on plan view is a simple method that shows completed area and remaining to be done, with green and red color. This method is connected with its related S-curve.
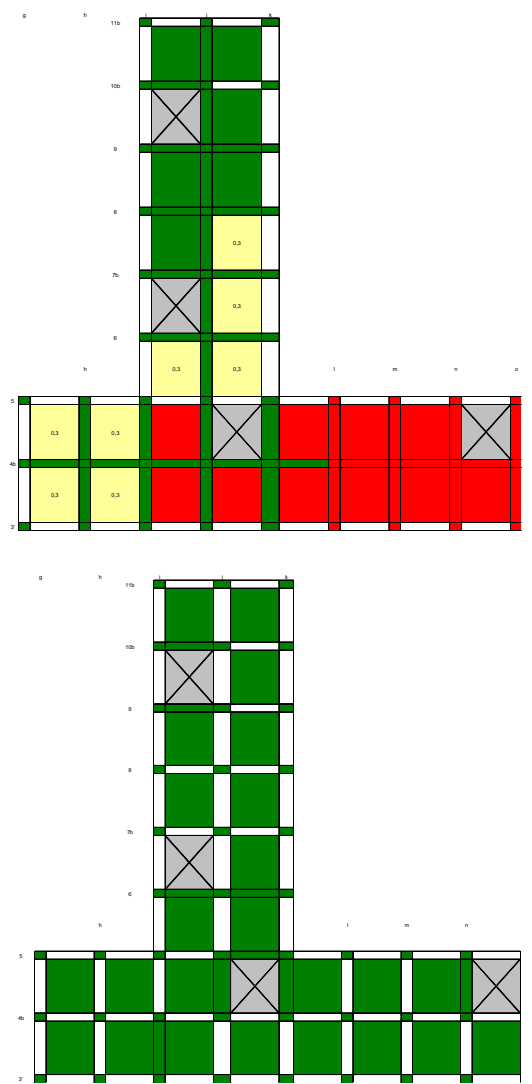


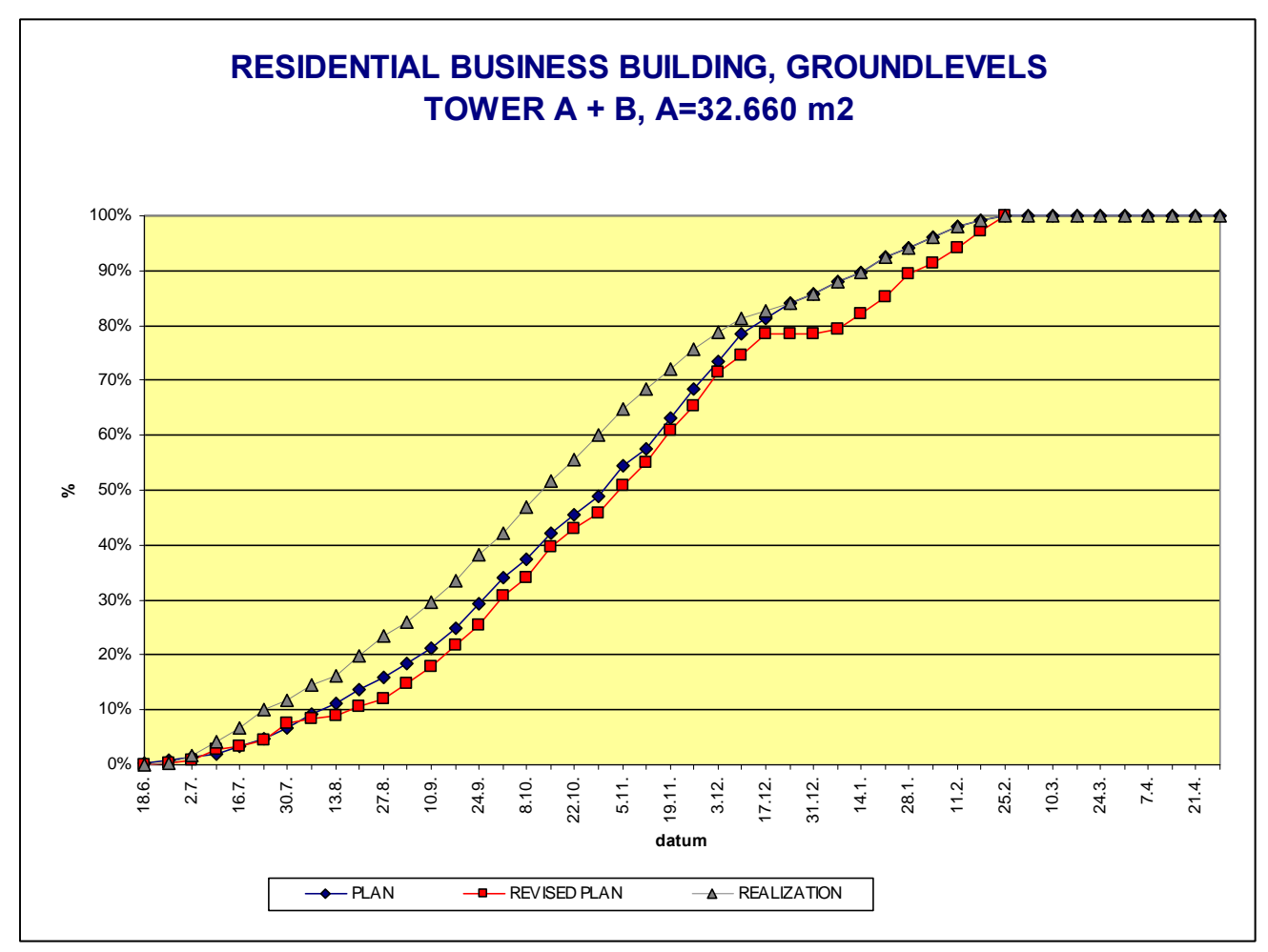

Fig. 4 S-curve of plan and realization progress.

Monitoring and controlling of realization of projects, no matter of a kind, make two questions those have to be answered:

- Is everything going on according to the plan?

- Is the project going to finish on time?

Monitoring reports can be regular, special or as separate analyses. Monitoring task is an early and clear direction to the changes and variation, and also showing trends and clear direction to the key data with great influence for the entirety.

Control is a process that compares planed parameters with the monitored ones. Control is continuous, very complex and responsible work, that has to be flexible, understanding to the work performers, easy to maintain, ethic, accurate, fully documented, directed to mistake corrections instead of punishing.

Processes of monitoring and controlling are integral and continuous through all phases of project. Full support of planning is provided by participation of members responsible for work progress of plan, which is accepted as their own.

\section{Conclusion}

The paper shows methods of planning, monitoring and controlling in Team Co. Method of S-curve is described as a simple model for prognosis and as a good base for decision-making. Every project is unique, so is the approach to planning individual using the existing and verified techniques. Team Co has central preparation of works sector, matrix organizational structure, own database for realized projects and also experience of project managers, so is the approach to the planning and organization of the projects systematic which enables good preparation, and it is well known that good preparation means half work done.

\section{References}

[1] Car-Pušić Diana and M. Radujković, Modeli za brzu procjenu održivog vremena građenja, Građevinar 58 (7) (2006) 559-568. Zagreb, Croatia. (in Croatian)

[2] B. Ivković and Ž. Popović, Upravljanje projektima u građevinarstvu, Nauka, Beograd, Serbia, 1995. (in Croatian) 
[3] J. Klepac, Organizacija građenja, Građevinski fakultet, Zagreb, Croatia, 1984. (in Croatian)

[4] A. Lester, Project Management, Planning and Control, Butterworth-Heinemann, Oxford, 2007

[5] R. Lončarić, Organizacija izvedbe graditeljskih projekata, HDGI, Zagreb, Croatia, 1995. (in Croatian)

[6] T. Marić, M. Radujković and A. Cerić, Upravljanje troškovima, vremenom i kvalitetom izgradnje u građevinskim projektima, Građevinar 59 (6) (2007) 485-493, Zagreb, Croatia. (in Croatian)

[7] R. Matotek, Ž. Bali and M. Horvat, Planning and organizing the projects in Team Co Čakovec, Croatia, 8th International Conference on Organzation, Tecnology and Management in Construction, Umag, Croatia, 2008.
[8] R. Matotek and M. Radujković, Workshop - Model of communication in Construction Company, 8th International Conference on Organization, Technology and Management in Construction, Umag, Croatia, 2008.

[9] PMI, A Guide to the Project Management Body of Knowledge, Project Management Institute, Upper Darby PA USA, 2000

[10] M. Radujković, Voditelj projekta, Građevinar 52 (3) (2000) 143-151, Zagreb, Croatia. (in Croatian)

[11] R. Raković, Kvalitet u upravljanju projektima, Građevinska knjiga, Beograd, Serbia, 2007. (in Croatian)

[12] Archive of Team Co, Croatia, Čakovec, Dobriše Cesarića St. 5. 